\title{
PENGGUNAAN YOUTOBE MENINGKATKAN HASIL BELAJAR DARING MATA PELAJARAN BAHASA ARAB KELAS VIIIA MTS NEGERI 5 KLATEN SEMESTER GANJIL TAHUN PELAJARAN 2020/2021
}

\author{
SRI SUWARNI DWI SAPUTRI \\ Guru Mata Pelajaran Bahasa Arab, MTs Negeri 5 Klaten, Jawa Tengah \\ e-mail : srisuwarnids71@ gmail.com
}

\begin{abstract}
ABSTRAK
Hasil belajar siswa selama masa pandemi melalui pembelajaran dalam jaringan (daring) rendah. Penelitian ini dilakukan dengan tujuan untuk meningkatkan hasil belajar siswa melalui penggunaan media video pembelajaran Youtube. Jenis penelitian yang digunakan adalah penelitian tindakan kelas (PTK). Subjek penelitian adalah peserta didik kelas VIIIA MTs N 5 Klaten dengan jumlah 24 peserta didik. Teknik pengumpulan data yang digunakan adalah tes dan dokumentasi. Teknik analisis data yang digunakan adalah analisis deskriptif kuantitatif. Hasil belajar peserta didik sebelum tindakan diperoleh data nilai rata-rata 76,67. Prosentase ketuntasan hasil belajar peserta didik sebelum tindakan sebesar 75,00\%. Pada akhir siklus I terjadi peningkatan hasil belajar siswa dengan nilai rata-rata 86,25. Prosentase ketuntasan hasil belajar peserta didik di akhir siklus I sebesar 87,50\%. Di akhir siklus II, kembali terjadi peningkatanhasil belajar peserta didik dengan nilai rata-rata 90,00. Sedangkan prosentase ketuntasan hasil belajar peserta didik di akhir siklus II sebesar 91,67\%. Dengan demikian, dapat disimpulkan bahwa penggunaan media video pembelajaran Youtube dalam pembelajaran daring dapat meningkatkan rata-rata nilai dan ketuntasan hasil belajar peserta didik.
\end{abstract}

Kata kunci: media pembelajaran, Youtube, hasil belajar daring,

\section{PENDAHULUAN}

Pandemi COVID-19 menimbulkan dampak di berbagai bidang kehidupan, salah satunya bidang pendidikan yang menyebabkan seluruh aktifitas belajar mengajar secara tatap mukadi kelas-kelas dihentikan. Sebagai gantinya, sesuai Surat Edara Mendikbud Nomor 4 tahun 2020 tentang aktifitas belajar mengajar dalam masa darurat COVID-19 dilaksanakan dari rumah melalui pembelajaran dalam jaringan atau daring. Kebijakan ini tentu saja menimbulkan berbagai permasalahan baru. Ketidakhadiran sosok guru bagi peserta didik, penggunaan media pembelajaran daring yang belum optimal, kesulitan orang tua peserta didik dalam mendampingi pelaksanaan pembelajaran daring, minimnya akses peserta didikterhadap gawai, dan berbagai kendala teknis pelaksanaan daring merupakan sekelumit masalah yang muncul saat ini.

Sementara untuk Kementerian Agama diberlakukan KMA 183 tahun 2019 tentang Kurikulum PAI dan Bahasa Arab di Madrasah pada tahun pelajaran 2020/2021. Sudah menjadi suatu hal yang biasa terjadi bahwa dengan adanya kurikulum baru pastilah ada perubahanperubahan terutama pada materi pembelajaran. Walaupun secara sigap dan tanggap Kementerian Agama meluncurkan system pembelajaran online dalam satu wadah di E-Learning Madrasah yang didalamnya secara lengkap dikemas secara keseluruhan pembelajaran seperti saat tatap muka. Namun demikian tetap ada kendala dan masalah yang timbul dalam pembelajaran.Terutama dengan Mata Pelajaran Bahasa Arab yang mayoritas peserta didik merasa kesulitan dan minder kalau tidak dapat memahaminya. Terutama bagi yang berasal dari SD yang belum pernah kenal dengan bahasa Arab sebelumnya walaupun ada pelajaran BTQ sehingga butuh motivasi khusus.Sehingga penulis sebagai guru bahasa Arab memberi kesempatan bagi yang merasa kesulitan untuk datang ke madrasah dan penulis berikan penjelasan yang diinginkan. Dampak dari permasalahan yang muncul di atas adalah hasil belajar peserta didik yang rendah, terlihat dari capaian rata-rata dan prosentase ketuntasan hasil belajar peserta didik pada Penilaian Harian 2. Rata-rata hasil belajar Penilaian Harian 2 diperoleh 76,67, dengan prosentase ketuntasan hasil belajar 75,00\% peserta didik tuntas. 
Pembelajaran daring merupakan sistem pembelajaran yang dilakukan dengan tidak bertatap muka langsung, tetapi menggunakan platform yang dapat membantu proses belajar mengajar yang dilakukan meskipun jarak jauh. Tujuan dari adanya pembelajaran daring ialah memberikan layanan pembelajaran bermutu dalam jaringan yang bersifat terbuka untuk menjangkau peminat ruang belajar agar lebih banyak dan lebih luas (Sofyana \& Abdul, 2019:82). Dalam pembelajaran daring, guru perlu memilih media pembelajaran yang tepat sehingga dapat menyampaikan materi pembelajaran dengan baik. Gerlach \& Elydikutip oleh Azhar Arsyad (2011: 7) menyatakan bahwa media pembelajaran memiliki cakupan yang sangat luas, yaitu termasuk manusia, materi atau kajian yang membangun suatu kondisi yang membuat peserta didik mampu memperoleh pengetahuan, keterampilan atau sikap. Menurut Syaiful Bahri Djamarah dan Aswan Zain (2010: 121) media pembelajaran adalah alat bantu apa saja yang dapat dijadikan sebagai penyalur pesan agar tercapai tujuan pembelajaran.

Perlu adanya upaya perubahan yang dilakukan untuk meningkatkan hasil belajar siswa pada pembelajaran daring. Sebelum adanya E-Learning Madrasah,guru hanya memberikan penjelasan dan materi pembelajaran daring melalui pesan singkat whatsapp. Namun karena dalam E-Learning Madrasah guru dapat menyampaikan bahan ajar dalam beberapa pilihan diantaranya : format Ms Word, format PDF, format Excel, format Power Point, Video, Link Artikel dan Gambar (format jpg). Dari beberapa pilihan tersebut penulis memilih Link Artikel atau dalam hal ini youtobe karena peserta didik dapat membuka dalam android dengan mudah dan dapat dibuka berulang-ulang.

Namun bukan suatu hal yang mudah dalam pencarian youtube yang sesuai dengan materi yang baru. Sehingga penulis pun tergerak untuk membuat youtobe dengan keterbatasan pengetahuan yang sangat minim dan hanya untuk kalangan sendiri saja. Menurut Budiargo (2015: 47) Youtube adalah video online dan yang utama dari kegunaan situs ini adalah sebagai media untuk mencari, melihat dan berbagi video yang asli ke dan dari segala penjuru dunia melalui suatu web. Berdasarkan penjelasan tersebut, maka penelitiberpendapat bahwa media pembelajaran yang disajikan dari Youtube merupakan suatu alat pengantar pesan dari guru kepada peserta didik dengan tujuan agar proses pembelajaran menjadi lebih baik, lebih menarik, dan memberikan pengaruh lebih baik terhadap hasil pembelajaran peserta didik. Dari video pembelajaran youtube diharapkan peserta didik dapat dengan mudah memahami materi pelajaran.

Tujuan yang ingin dicapai dalam penelitian ini adalah untuk mengupayakan dan mengetahui peningkatan hasil belajar peserta didik kelas VIIIA MTs Negeri 5 Klaten dalam pembelajaran daring melalui pemanfaatan media video pembelajaran Youtube. Dengan pemanfaatan media video pembelajaran youtube diharapkan dapat meningkatkan hasilbelajar daring peserta didik kelas VIIIA MTs Negeri 5 Klaten dibandingkan dengan hasil belajar sebelumnya.

\section{METODE PENELITIAN}

\section{Prosedur Penelitian}

Prosedur penelitian yang digunakan dalam penelitian ini adalah penelitian tindakan kelas. Menurut Ridwan (2020: 1), penelitian tindakan adalah penelitian yang berorientasi pada penerapan tindakan dengan tujuan meningkatkan mutu atau menyelesaikan masalah pada suatu kelompok subjek yang diteliti dan mengamati tingkat keberhasilan atau akibat tindakan yang dilakukan. Sedangkan Kemmis (dalam Ridwan, 2020: 4) mendefinisikan penelitian tindakan sebagai suatu bentuk penelaahan atau inkuiri melalui refleksi diri yang dilakukan oleh peserta kegiatan pendidikan tertentu (misalnya guru atau kepala sekolah) dalam situasi sosial (termasuk pendidikan) untuk memperbaiki rasionalitas dan kebenaran serta keabsahan dari (a) praktik-praktik sosial kependidikan yang mereka lakukan sendiri, (b) pemahaman mereka mengenai praktik-praktik tersebut, dan (c) situasi kelembagaan tempat praktik-praktik itu dilaksanakan. Classroom action research atau penelitian tindakan kelas sebenarnya tidak terlalu dikenal di luar negeri. Istilah ini dikenal di Indonesia untuk 
suatu penelitian tindakan yang diaplikasikan dalam kegiatan belajar mengajar di kelas dengan maksud memperbaiki pembelajaran (Ridwan, 2020: 3). Peneliti melakukan penelitian tindakan kelas model Kemmis dan McTaggart dengan langkah-langkah pelaksanaan penelitian seperti ilustrasi gambar berikut ini:

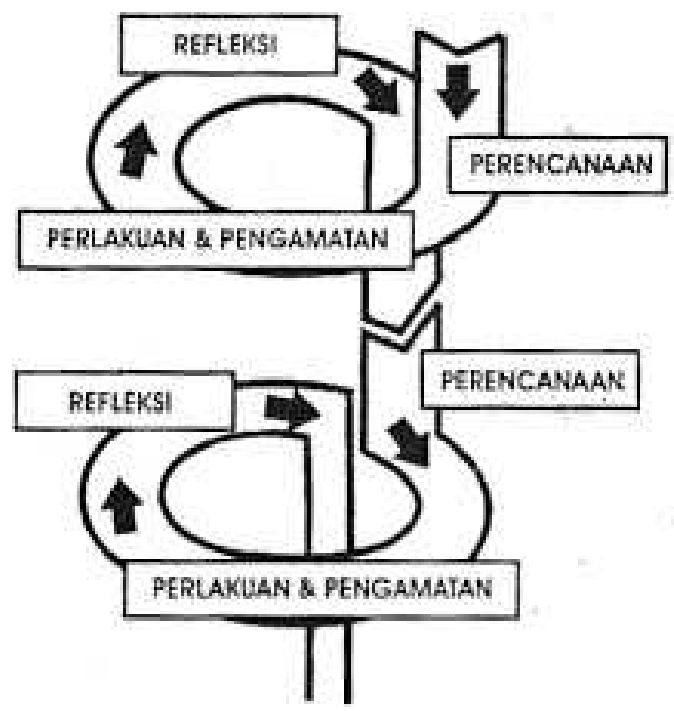

Gambar 1. Siklus PTK menurut Kemmis (dalam Ridwan, 2020: 28)

Penelitian dilaksanakan dalam dua siklus dengan masing-masing siklus terdiri dari tahap perencanaan, tindakan dan pengamatan, dan refleksi. Dalam siklus I, tahap perencanaan dimulai dengan penyusunan perangkat pembelajaran secara lengkap (RPP, bahan ajar, media, dan evaluasi), melakukan koordinasi dan sosialisasi pelaksanaan penelitian bersama rekan sejawat dan siswa, serta menyiapkan perangakat keras dan lunak untuk pelaksanaan pembelajaran daring melalui aplikasi E-Learning Madrasah yang dibuat oleh Kementerian Agama untuk mempermudah dan memperlancar pembelajaran dimasa pandemi ini. Selanjutnya pelaksanaan tindakan melalui pelaksanaan pembelajaran daring berbasis aplikasi E-Learning Madrasah yang didalamnya memuat semua unsur pembelajaran yang sangat lengkap menurut penulis.

Terakhir pelaksanaan refleksi, yaitu tahap di mana hasil pengamatan dan evaluasi tindakan yang telah dilakukan dalam pembelajaran dikumpulkan dan dianalisis. Hasil analisis kemudian direfleksikan dan digunakan sebagai dasar acuan merancang siklus II.

Dalam siklus II, hasil refleksi siklus I digunakan untuk merencanakan dan merancang siklus II. Kegiatan siklus II meliputi perancangan perangkat pembelajaran daring, sosialisasi waktu pelaksanaan tindakan kepada siswa, dan persiapan hardware maupun software yang akan digunakan. Dilanjutkan dengan langkah pemberian tindakan dan pengamatan melalui kegiatan pembelajaran daring berbasis aplikasi E-Learning Madrasah dan Google Form. Sebagai kegiatan terakhir dalam siklus II akan dilaksanakan refleksi berupa analisis data yang telah terkumpul dan pengambilan kesimpulan pelaksanan penelitian tindakan.

\section{Subjek dan Objek Penelitian}

Subjek penelitian ini adalah peserta didik kelas VIIIA MTs Negeri 5 Klaten dengan jumlah 24peserta didik. Objek penelitian ini adalah hasil belajar daring peserta didik dengan pemanfaatan media video pembelajaran Youtube.

\section{Metode Pengambilan Data}

Teknik pengumpulan data dalam penelitian ini dilakukan dengan metode tes evaluasi hasil belajar dan dokumentasi menggunakan aplikasi E-Learning Madrasah. 


\section{Kriteria Ketuntasan Tindakan}

Aspek yang menjadi tolok ukur keberhasilan dalam penelitian ini adalah peningkatan hasil belajar daring siswa yang ditunjukkan dengan kenaikan nilai rata-rata dan prosentase ketuntasan hasil belajar siswa dengan kriteria ketuntasan minimal (KKM) kelas 65.

\section{Analisis Data}

Hasil belajar siswa dianalisis dengan teknik analisis data secara deskriptif kuantitatif yaitu dengan menjumlahkan skor perolehan dibagi dengan skor maksimal, kemudian dikalikan 100. Adapun rumusnya menggunakan rumus menurut Suharsimi Arikunto (2002:183). Berikut rumusnya:

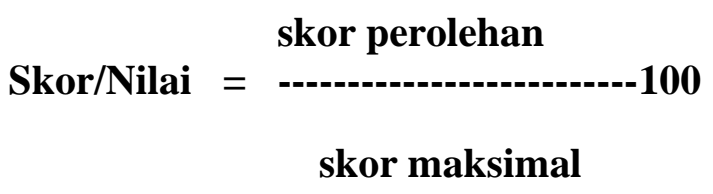

Analisis nilai hasil belajar dilakukan dengan menghitung nilai rata-rata kelas, kemudian hasilnya dikualifikasikan dengan menggunakan pedoman sebagai berikut:

Tabel 1. Kualifikasi Nilai Rata-Rata Kelas

\begin{tabular}{ccc}
\hline No. & Nilai Rata-Rata Kelas & Kualifikasi \\
\hline 1. & $81 \leq \mathrm{x} \leq 100$ & Baik \\
\hline 2. & $61 \leq \mathrm{x} \leq 80$ & Cukup \\
\hline 3. & $41 \leq \mathrm{x} \leq 60$ & Kurang \\
\hline 4. & $21 \leq \mathrm{x} \leq 40$ & Rendah \\
\hline 5. & $0 \leq \mathrm{x} \leq 20$ & Sangat Rendah
\end{tabular}

Keterangan: $\mathrm{x}=$ nilai rata-rata kelas

Adapun kualifikasi prosentase ketuntasan dilakukan dengan menghitung banyak peserta didikyang memperoleh nilai hasil belajar di atas KKM kelas 65. Selanjutnya dihitung prosentase ketuntasan dengan membanding banyak peserta didik yang tuntas dibanding jumlah seluruh peserta didik. Kemudian dikualifikasi dengan menggunakan pedoman sebagai berikut:

Tabel 2. Kualifikasi Prosentase Ketuntasan Hasil Belajar

\begin{tabular}{ccc}
\hline No. & Prosentase Ketuntasan & Kualifikasi \\
\hline 1. & $81 \% \leq \mathrm{x} \leq 100 \%$ & Baik \\
\hline 2. & $61 \% \leq \mathrm{x} \leq 80 \%$ & Cukup \\
\hline 3. & $41 \% \leq \mathrm{x} \leq 60 \%$ & Kurang \\
\hline 4. & $21 \% \leq \mathrm{x} \leq 40 \%$ & Rendah \\
\hline 5. & $0 \leq \mathrm{x} \leq 20 \%$ & Sangat Rendah
\end{tabular}

Keterangan: $\mathrm{x}$ adalah prosentase ketuntasan hasil belajar peserta didik.

\section{HASIL DAN PEMBAHASAN}

\section{Hasil Penelitian}

Hasil penelitian yang telah dilaksanakan dengan pemanfaatan media video 
pembelajaran Youtube dalam pembelajaran daring menunjukkan peningkatan rata-rata hasil belajar dan prosentase ketuntasan hasil belajar peserta didik kelas VIIIA MTs Negeri 5 Klaten. Berikut adalah sajian data hasil penelitiannya:

Tabel 3. Nilai Rata-Rata Kelas pada Prasiklus, Siklus I, dan Siklus II

$\begin{array}{clccc}\text { No. } & \text { Keterangan } & \text { Prasiklus } & \text { Siklus I } & \text { Siklus II } \\ \text { 1. } & \text { Rata-Rata Nilai Kelas } & 76,67 & 86,25 & 91,67\end{array}$

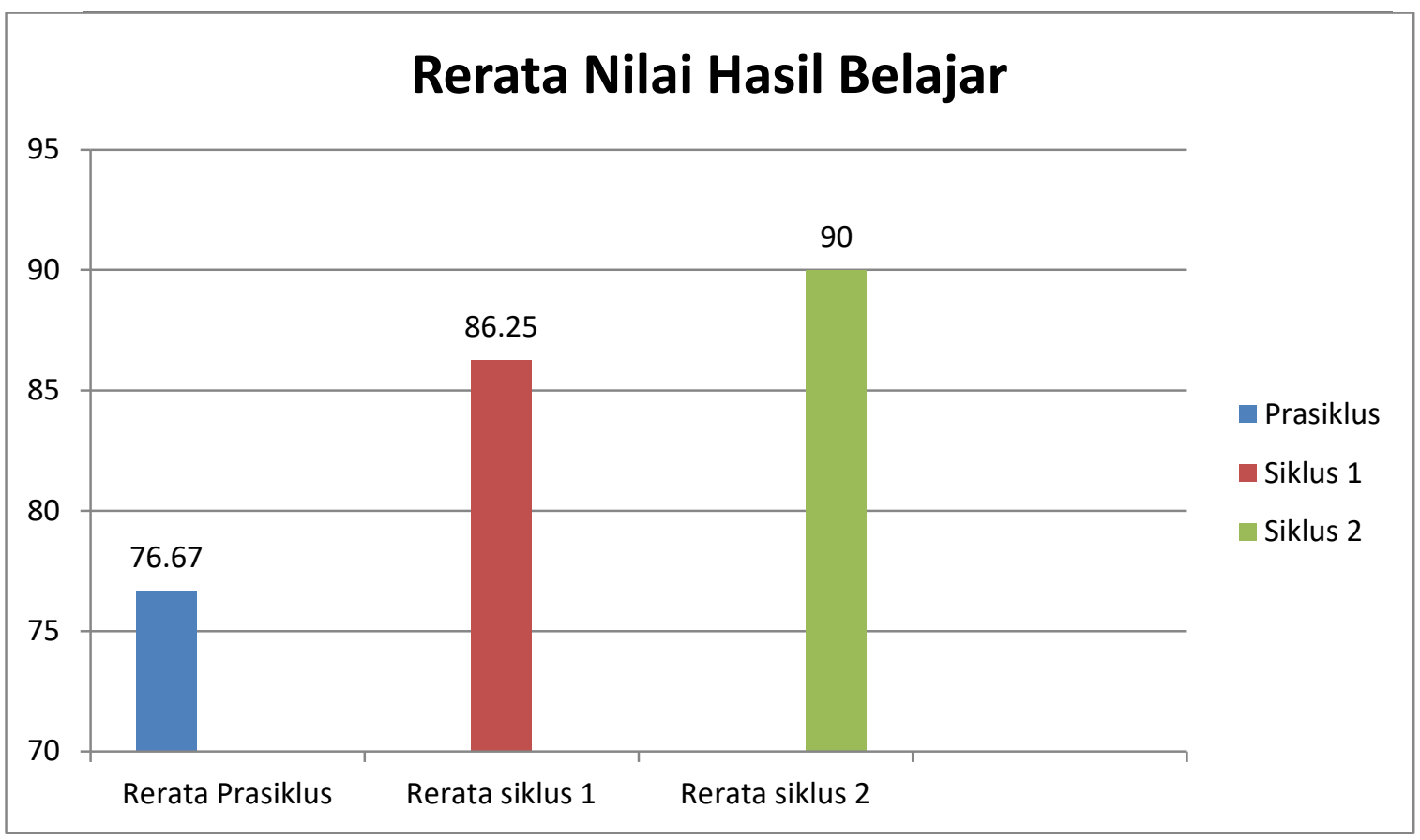

Gambar 2. Histogram Perbandingan Nilai Rata-Rata Kelas pada Prasiklus, Siklus I,dan Siklus II

Tabel 3 dan gambar 2 menunjukkan perbandingan nilai hasil belajar prasiklus, siklus I, dan siklus II. Dari data tabel di atas dapat terlihat bahwa hasil belajar setelah dilakukan tindakan pemanfaatan media video pembelajaran Youtube dalam pembelajaran daring mengalami peningkatan. Pada prasiklus rerata nilai hasil belajar peserta didik 76,67 (cukup) meningkat menjadi 86,25 (baik) pada akhir siklus I, dan meningkat menjadi 90,00 (baik) pada akhir siklus II.

Tabel 4. Prosentase Ketuntasan Peserta Didik pada Prasiklus, Siklus I, dan Siklus II

\begin{tabular}{|c|c|c|c|c|c|c|c|}
\hline \multirow[t]{2}{*}{ No. } & \multirow[t]{2}{*}{ Keterangan } & \multicolumn{2}{|c|}{ Prasiklus } & \multicolumn{2}{|c|}{ Siklus I } & \multicolumn{2}{|c|}{ Siklus II } \\
\hline & & $f$ & $\%$ & $\mathrm{f}$ & $\%$ & $\mathrm{f}$ & $\%$ \\
\hline 1. & Jumlah Peserta Didik Yang Tuntas & 18 & 75,00 & 21 & 87,50 & 22 & 91,67 \\
\hline 2. & $\begin{array}{l}\text { Jumlah Peserta Didik Yang Tidak } \\
\text { Tuntas }\end{array}$ & 6 & 25,00 & 3 & 12,50 & 2 & 8,33 \\
\hline
\end{tabular}




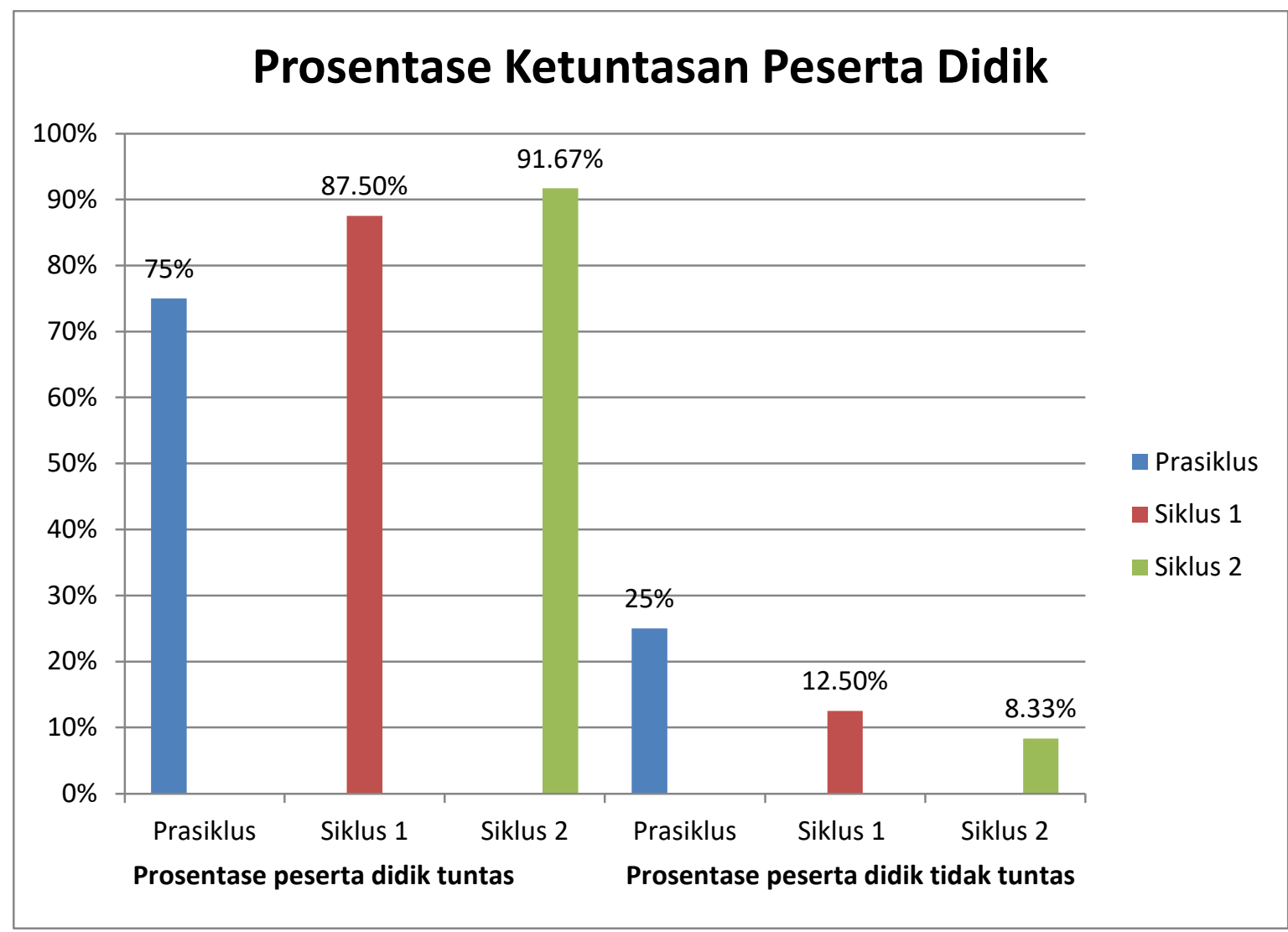

\section{Gambar 3. Histogram Prosentase Ketuntasan Peserta Didik pada Prasiklus, Siklus I, danSiklus II}

Tabel 4 dan gambar 3 menunjukkan banyak siswa yang tuntas atau memperoleh nilai diatas KKM 65 pada saat sebelum tindakan atau prasiklus ada 18 peserta didik dan yang tidak tuntas ada 6 peserta didik dari total 24 peserta didik. Pada akhir siklus I, jumlah peserta didik yang tuntas meningkat menjadi 21 peserta didik dan jumlah peserta didik yang tidak tuntas menurun menjadi 3 peserta didik. Setelah pemberian tindakan siklus II, diperoleh hasil 22 peserta didik tuntas dan tinggal 2 peserta didik yang tidak tuntas dari total 24 peserta didik. Jika dibuat prosentase, maka ketuntasan peserta didik pada prasiklus 75,00\% (cukup), meningkat menjadi 87,50\% di akhir siklus I (baik), dan meningkat kembali pada akhir siklus II dengan prosentase $91,67 \%$ (baik). Sedangkan prosentase peserta didik tidak tuntas sebelum tindakan sebesar $25,00 \%$, kemudian mengalami penurunan setelah tindakan siklus I menjadi $12,50 \%$, dan di akhir siklus II prosentase peserta didik tidak tuntas turun drastis menjadi 8,33\%. Dari data tabel 4 dan gambar 3 di atas dapat terlihat bahwa jumlah dan prosentase peserta didik yang tuntas setelah dilakukan tindakan pemanfaatan media video pembelajaran Youtube dalam pembelajaran daring mengalami peningkatan.

\section{Pembahasan}

Berdasarkan hasil penelitian yang sudah dilaksanakan pada peserta didik kelas VIIIA MTs Negeri 5 Klaten semester 1 tahun pelajaran 2020/2021 dengan pemanfaatan media video pembelajaran Youtube dalam pembelajaran daring menunjukkan adanya peningkatan hasil belajar dari sebelum tindakan, siklus I, hingga siklus II. Data rata-rata nilai hasil belajar peserta didik sebelum tindakan atau prasiklus yang diperoleh dari hasil Penilaian Harian 2 adalah 76,67 dengan kualifikasi cukup. Peningkatan hasil belajar diperoleh setelah dilakukan tindakan pada siklus I dengan nilai rata-rata kelas 86,25 dengan kualifikasi baik pada siklus 1 . Penelitian dilanjutkan dengan tindakan siklus II dengan perolehan nilai rata-rata kelas hasil belajar 
meningkat menjadi 90,00 dengan kualifikasi baik.

Prosentase ketuntasan hasil belajar daring siswa dengan KKM 65 juga mengalami peningkatan yaitu ditandai dengan prosentase ketuntasan sebelum tindakan sebesar 75,00\% dengan kualifikasi cukup. Setelah dilakukan tindakan dengan pemanfaatan media video pembelajaran Youtube pada pembelajaran daring, maka prosentase ketuntasan hasil belajar meningkat menjadi $87,50 \%$ pada siklus I dan meningkat kembali menjadi $91,67 \%$ pada akhir siklus II.

Hasil penelitian ini sesuai dengan penelitian yang dilakukan sebelumnya oleh Akhmad Busyaeri, Tamsik Udin, A. Zaenuddin (2016) di mana pembelajaran dengan memanfaatkan media video pembelajaran menyebabkan nilai rata-rata hasil belajar mencapai 80,63 (baik). Hasil penelitian ini juga sesuai dengan penelitian yang dilakukan oleh Tri Suwarno Handoko Noviyanto dan Nengsih Juanengsih, Eny S. Rosyidatun (2015) yang berhasil meningkatkan hasil belajar Biologi dengan menggunakan video pembelajaran berupa animasi pernapasan manusia. Tindakan dalam penelitian ini berhasil karena guru belum pernah melakukan pemanfaatan media video pembelajaran Youtube dalam upaya meningkatkan hasil belajar siswa, siswa antusias dan lebih tertarik pada media pembelajaran berbasis video yang mengandung unsur audio visual, dan siswa dapat mengakses kembali media video pembelajaran ini kapan saja dan di mana saja. Pengembangan diri siswa untuk menunjang kompetensi profesional guru (Hartini, 2019). Kompetensi profesional dilaksanakan melalui penelitian (Supriyanto, Hartini, Syamsudin, and Sutoyo, 2019).

Pembahasan tentang penggunaan youtobe dalam pembelajan bahasa Arab yaitu youtobe dapat membuat peserta didik akan semakin tertarik mempelajari bahasa Arab, youtobe dapat menciptakan realisasi dan relevansi, dengan apa yang dirasakan peserta didik, youtobe dapat meningkatkan hasil belajar peserta didik, youtobe dapat meningkatkan kompetensi guru dalam mengajar bahasa Arab, youtobe mampu memberikan kemudahan dalam pembelajaran bahasa Arab dimasa pandemi ini.

\section{KESIMPULAN}

Berdasarkan hasil dan pembahasan di atas, maka dapat disimpulkan bahwa pemanfaatan media video pembelajaran Youtube dalam pembelajaran daring dapat meningkatkan hasil belajar daring kelas VIIIA MTs Negeri 5 Klaten semester 1 tahun pelajaran 2020/2021. Hal ini dapat dilihat dari hasil penelitian bahwa terjadi peningkatan nilai rata-rata kelas pada sebelum tindakan sebesar 76,67 dengan kualifikasi cukup, meningkat menjadi 86,25 dengankualifikasi baik pada siklus I, dan meningkat kembali menjadi 90,00 dengan kualifikasi baik pada akhir siklus II. Peningkatan prosentase ketuntasan hasil belajar daring juga terjadi pada sebelum tindakan sebesar $75,00 \%$, meningkat menjadi $87,50 \%$ pada siklus I, dan meningkat menjadi 91,67\% pada akhir siklus II.

\section{DAFTAR PUSTAKA}

Arikunto, Suharsimi., dkk. (2008). Penelitian Tindakan Kelas. Jakarta: Bumi Aksara. Arsyad. Azhar. (2011). Media Pembelajaran Cet. 14, Jakarta, Raja Grafindo Persasda.

Asyar, Rayandra. (2012). Kreatif Mengembangkan Media Pembelajaran. Jakarta: Gaung PersadaPress.

Budiargo, Dian. (2015). Berkomunikasi ala Net Generation. Jakarta: PT Elex Media KomputindoKompas Gramedia.

Dimyati dan Mudjiono. (2009). Belajar dan Pembelajaran. Jakarta: Rineka Cipta.

Djamarah, Syaiful Bahri dan Aswan Zain. (2010). Strategi Belajar Mengajar. Jakarta: Rineka Cipta.

Hartini, S. (2019). Kompetensi Profesional Guru dalam Meningkatkan Motif Berprestasi Peserta Didik: Studi di SDN Karangpucung 04 dan SDN Karangpucung 05 Kabupaten Cilacap. Indonesian Journal of Education Management \& Administration Review, 3(1), 71- 76. 
Keputusan Menteri Agama Republik Indonesia, Nomor 183 Tahun ( 2019), Tentang

Kurikulum Mata Pelajaran Pendidikan Agama Islam dan Bahasa Arab Pada Madrasah Kunandar, (2009). Penelitian Tindakan Kelas Sebagai Pengembangan Profesi Guru. Jakarta:Rajawali Pers

Noviyanto, Tri Suwarno Handoko, dkk. (2015). "Penggunaan Media Video Animasi Sistem Pernapasan Manusia Untuk Meningkatkan Hasil Belajar Biologi”. EDUSAINS. Vol. 7 No. 12015.

Sani, Dr. Ridwan Abdullah, dkk. (2020). Panduan Praktis Penelitian Tindakan Kelas.

Bandung: PT.Remaja Rosdakarya.

Supriyanto, A., Hartini, S., Syamsudin, S., \& Sutoyo, A. (2019). Indicators of professional competencies in research of Guidance and Counseling Teachers. Counsellia: Jurnal BimbingandanKonseling,9(1),53-64 